\title{
The taxonomic implication of leaf micromorphological characteristics in the genus Aruncus (Rosaceae)
}

\author{
Min-Kyeong OAK ${ }^{1}$, Jun-Ho SONG ${ }^{1,2}$ and Suk-Pyo HONG ${ }^{1 *}$ \\ ${ }^{1}$ Laboratory of Plant Systematics, Department of Biology, Kyung Hee University, Seoul 02447, Korea \\ ${ }^{2}$ Herbal Medicine Research Division, Korea Institute of Oriental Medicine, Daejeon 34054, Korea \\ (Received 22 February 2018; Revised 31 May 2018; Accepted 14 June 2018)
}

\begin{abstract}
A comparative study of leaf epidermal microstructures in genus Aruncus (two species, five varieties) was carried out using scanning electron microscopy in order to evaluate their significance in terms of taxonomy. All of the leaves of the taxa studied here were amphistomatic with undulate anticlinal walls, and smooth and flat periclinal walls on both surfaces. The size range of the stomata complex is 8.95-21.97 $\times 7.50-16.99 \mu \mathrm{m}$ : the largest one was found in Aruncus dioicus var. astilboides (average $18.01 \times 13.47 \mu \mathrm{m}$ ) and the smallest was measured and determined to be $A$. gombalanus (average $11.11 \times 8.94 \mu \mathrm{m}$ ). An anomocytic stomata complex was found in all of the studied taxa. The stomatal frequency on average was $27.54 / 0.05 \mathrm{~mm}^{2}$; it is highest in $A$. gombalanus $\left(60.4 / 0.05 \mathrm{~mm}^{2}\right)$ and lowest in A. dioicus var. acuminatus $\left(11.6 / 0.05 \mathrm{~mm}^{2}\right)$. Two types (short stalked capitate glandular trichome and non-glandular trichome) of trichomes are found in the leaves. The non-glandular trichome was divided into three types based on the presence and degree of development of subsidiary cells. Anomocytic stomata of the hypostomatic type and the distribution pattern of capitate glandular trichomes were the major characters in this genus. The stomata size and frequency, the epidermal cell structure, the trichome type and the distribution pattern may have diagnostic importance among the taxa in the genus. Our leaf micromorphological results provide useful information for the taxonomic revision of the genus Aruncus.
\end{abstract}

Keywords: leaf epidermal cell, stomata complex, glandular trichome, Aruncus, Rosaceae

눈개승마속(Aruncus L.)은 전통적으로 장미과(Rosaceae Juss.)내의 조팝나무아과(subfamily Spiraeoideae Agardh)에 속하는 분류군으로서, 북반구 온대지역 전반에 걸쳐 분포 한다. 본 속은 다년생 초본으로, 2 또는 3 회 우상복엽이고, 탁엽은 없으며, 화판과 악편은 4장 이상으로, 이생하고, 외악편은 없으며, 심피는 3 또는 4(-8)개로, 혁질의 골돌과 를 갖는 특성을 지녀, 과 내 다른 속 식물들과 뚜렷이 구분 된다(Hutchinson, 1964; Ikeda, 2001; Gu and Alexander, 2003; Kalkman, 2004; Lee, 2007; Mellichamp, 2014). 한편, 유럽에 서는 관상용, 약용식물로 재배되기도 한다(Yuzepchuk, 1939; Tutin, 1968).

눈개승마속은 Fernald (1939)가 Actaea dioica Walter를 본 속으로 전속하여 인식한 이후로부터 많은 학자들에 의해 종 또는 종하위 분류군이 포함되는 것으로 인식되고 있다. Hara (1955)는 지리적 변이와 함께 소엽의 형태와 크기, 털 의 유무, 화피편, 악편의 크기, 화주의 길이, 골돌의 크기
등의 형질 차이로 총 1 종 12 변종 1 품종으로 인식하였다. $\mathrm{Gu}$ and Alexander (2003)는 Aruncus gombalanus (Hand.Mazz.) Hand.-Mazz., A. sylvester Kostel. ex Maxim., 2종이 중국에 분포하는 것으로 인식하였으며, Mellichamp (2014) 는 북미에 A. dioicus (Walter) Fernald를 포함하여, 총 1종 3 변종이 분포하는 것으로 보고하였다. 국내에는 일반적으 로 A. aethusifolius (H. Lév.) Nakai, A. dioicus var. kamtschaticus (Maxim.) H. Hara, 1종 1변종이 분포하는 것 으로 보고되어 있으나(Lee, 2007), A. sylvester 1종이 분포 하는 것으로 인식하기도 한다(Chang et al., 2014). 이처럼 본 속은 형태적으로 나타나는 연속적인 변이로 인해 학자 간 속 내 분류군의 인식이 상이하나, 주로 외부형태학적 형질, 그 중에서도 잎의 형태형질(소엽의 형태 및 크기, 엽 선의 형태, 엽연의 형태 및 결각의 정도, 털의 유무 등)이 분류군을 구분하는 중요한 식별형질로서 사용되어 왔다 (Rydberg, 1908; Hara, 1955; Gu and Alexander, 2003; Lee,

\footnotetext{
*Author for correspondence: sphong@khu.ac.kr
} 
2007; Pathak and Bhaumik, 2012; Mellichamp, 2014). A. gombalanus는 소엽 및 엽선 형태 등의 차이를 바탕으로 종 수준으로 인식되고 있고 $(\mathrm{Gu}$ and Alexander, 2003; Pathak and Bhaumik, 2012), A. dioicus의 종하위 분류군의 경우 기 본종에 비해 엽선이 긴 점첨두인 특징으로 A. dioicus var. acuminatus (Rydb.) H. Hara, 엽연이 깊게 갈라지는 특징으 로 A. dioicus var. aethusifolius (H. Lév.) H. Hara로 인식되어 구별되며(Rydberg, 1908; Hara, 1955), A. dioicus var. pubescens (Rydb.) Fernald는 잎 하면에 털이 밀생하는 특징 을 지닌다(Mellichamp, 2014). 하지만, 기공복합체, 표피세 포의 형태, 모용의 유형 등 잎 표피 미세형태학적 연구는 전무한 실정이다.

잎 표피 미세형태형질은 분류학적 중요성으로 인해 다 양한 분류군에서 연구가 시도되었고, 현재까지 많은 피자 식물군 내에서 그 분류학적, 계통학적 유용성이 검증되었 다(Wilkinson, 1979; Stace, 1984; Zhou et al., 1994; Yang and Lin, 2005; Zorić et al., 2009; Anil Kumar and Murugan, 2013; Deng et al., 2014; Kang et al., 2017). 특히 잎 표피의 미세형 태와 함께 모용(trichome)의 종류, 분포 등의 형질은 본 속 이 속하는 장미과 내의 다양한 분류군에서 식별형질로의 유용성이 이미 검증된 바 있다(Eriksen and Yurtsev, 1999; Faghir et al., 2010; Ganeva and Uzunova, 2010; Heo et al., 2013; Faghir et al., 2014; Tomaszewski et al., 2014; Song and Hong, 2016, 2017). 동일 과 내 다양한 분류군에서 형질의 유용성이 검증된 바 있음에도, 눈개승마속 분류군들에 대 한 정보는 일부 분류군에 한하여 육안으로 확인되는 모용 의 분포양상만이 알려져 있다. A. dioicus var. dioicus를 포 함한 종하위 분류군에서는 중륵을 따라 모용이 드물게 존 재하거나 간혹 존재하지 않는다고 보고된 바 있으며 (Yuzepchuk, 1939; Ikeda, 2001), A. dioicus var. pubescens에 서는 배축면에 모용이 밀생하는 특징으로 뚜렷하게 구별 되어 변종으로 인식되고 있다(Rydberg, 1908; Hara, 1955; Mellichamp, 2014). 또한 A. gombalanus의 경우, 중륵을 따 라 모용이 밀생한다고 보고된 바 있다 $(\mathrm{Gu}$ and Alexander, 2003; Pathak and Bhaumik, 2012). 따라서, 본 속 내 분류군 전반의 잎 표피 미세형태학적 형질에 대해 일관성 있는 형질조사와 자세한 기재가 필요하며, 종 또는 종 이하 분 류군의 한계설정을 위한 형질로서 활용될 수 있을 지 검 토할 필요가 있다.

한편, 잎의 미세형태학적 형질은 유전적 요인과 함께 개 체의 생육환경에도 영향을 받는다고 알려져 있다(Stace, 1984). 눈개승마속의 분포양상을 고려해 볼 때, 북반구에 걸쳐 연속적으로 넓게 분포하는 A. dioicus var. dioicus와 달 리 속 내 일부 분류군의 경우 지리적으로 제한된 분포역 을 나타낸다. 대표적으로 A. gombalanus는 중국 남부 및 서 남부와 인도에 제한적으로 분포하며(Pathak and Bhaumik, 2012), A dioicus var. astilboides는 일본 혼슈의 하야치네산 에서만 생육하고(Ikeda, 2001), A. dioicus var. aethusifolius는
한반도 제주도의 한라산에만 자생하는 것으로 보고된 바 있다(Lee, 1980; Lee, 2007). 따라서, 본 속 분류군이 나타내 는 잎 표피 미세형태학적 형질의 변이는 외부 형태학적 형질과 함께 생육환경의 생태적 조건 및 식물의 적응에 대한 이해를 도울 수 있을 것으로 사료된다.

이에, 본 연구에서는 눈개승마속 분류군들에 대하여 기 본적으로 Hara (1955)의 분류체계에 따라 선험적으로 동 정 후, 잎의 표피세포, 기공 및 모용의 미세형태학적 형질 을 상세하게 관찰, 기재함으로써 본 속이 갖는 미세형태 학적 형질의 기초자료를 확보함과 동시에, 이들 형질의 종 또는 종하위 분류군 간 변이양상을 규명하고, 인식형 질로서의 분류학적 유용성을 검증하고자 하였다. 또한, 조사된 미세형태와 개체의 지리적 분포 및 생육환경을 고 려하여 이들 식물이 나타내는 적응양상을 확인하는 데 그 의의가 있다.

\section{재료 및 방법}

본 연구에서는 눈개승마속 7분류군(2종, 5 변종)의 석엽 표본을 국내·외표본관(F, KB, KHUS, NY, PE, and TI, abbreviations according to Thiers, 2017)으로부터 대여하거 나 직접 채집한 생체표본을 사용하였으며, 실험에 사용된 표본의 목록은 Appendix 1에 제시하였다. 시료 및 표본은 기존에 제시된 Hara (1955)의 분류체계에 따라 선험적으 로 동정 후 실험에 사용하였다.

국내 분류군을 포함하여 본 속에 속하는 분류군은 동일 분류군 내에서도 잎의 결각 및 형태가 다양하게 나타났다 (Fig. 1). 따라서, 동일 종 내에서 2개체 이상을 실험에 사용 하였고, 모두 동일한 조건으로 정소엽(terminal leaflet)을 관 찰하였다. 식물의 성숙한 잎을 선별하여, 모용의 분포를 관 찰하기 위해 해부현미경(streomicroscope, SteREO Discovery. V8, Carl Zeiss Microscopy GmbH, Jena, Germany)을 사용하였 으며, 주사전자현미경(scanning electron microscope, SEM)을 이용하여 잎의 미세형태학적 형질을 관찰하였다. 직접 채 집한 생체표본은 FAA (40\% formalin: $40 \%$ glacial acetic acid: $70 \%$ ethyl alcohol) mixture에 고정 후 장기 보관하여 사 용하였고, 이미 건조된 표본의 경우 약 $90^{\circ} \mathrm{C}$ 에서 3 분간 끓 이거나 연화제(Agepon, Agfa Gevaert, Leverkusen, Germany; Agepon wetting agent: distilled water, 1:200)에 넣 어 24시간 이상 담가 조직을 부드럽게 한 후, $70 \%$ ethyl alcohol에 보관하여 실험에 사용하였다. 잎의 미세학적 형 질을 관찰하기 위해서 $70 \%$ ethyl alcohol에 보관된 시료는 알코올시리즈(alcohol series: 50\%, 60\%, 70\%, 80\%, 90\%, $100 \%$ 에서 각각 30 분 정도 보관)를 거쳐 탈수한 후, 이산화 탄소 가스 $\left(\mathrm{CO}_{2}\right)$ 를 이용한 임계점 건조 처리(critical point drying; SPI-13200J-AB, SPI Supplies, West Chester, PA, USA) 를 하여 완전하게 건조시켰다. 건조된 시료는 알루미늄 스터브(aluminum stub) 위에 올린 다음 이온 증착기 
A

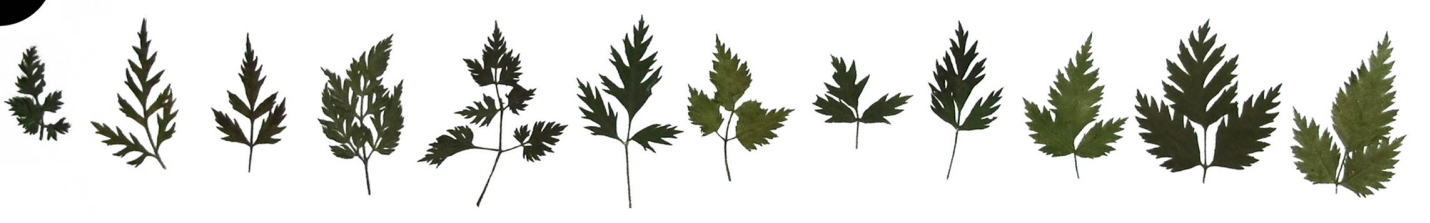

B $2 v$
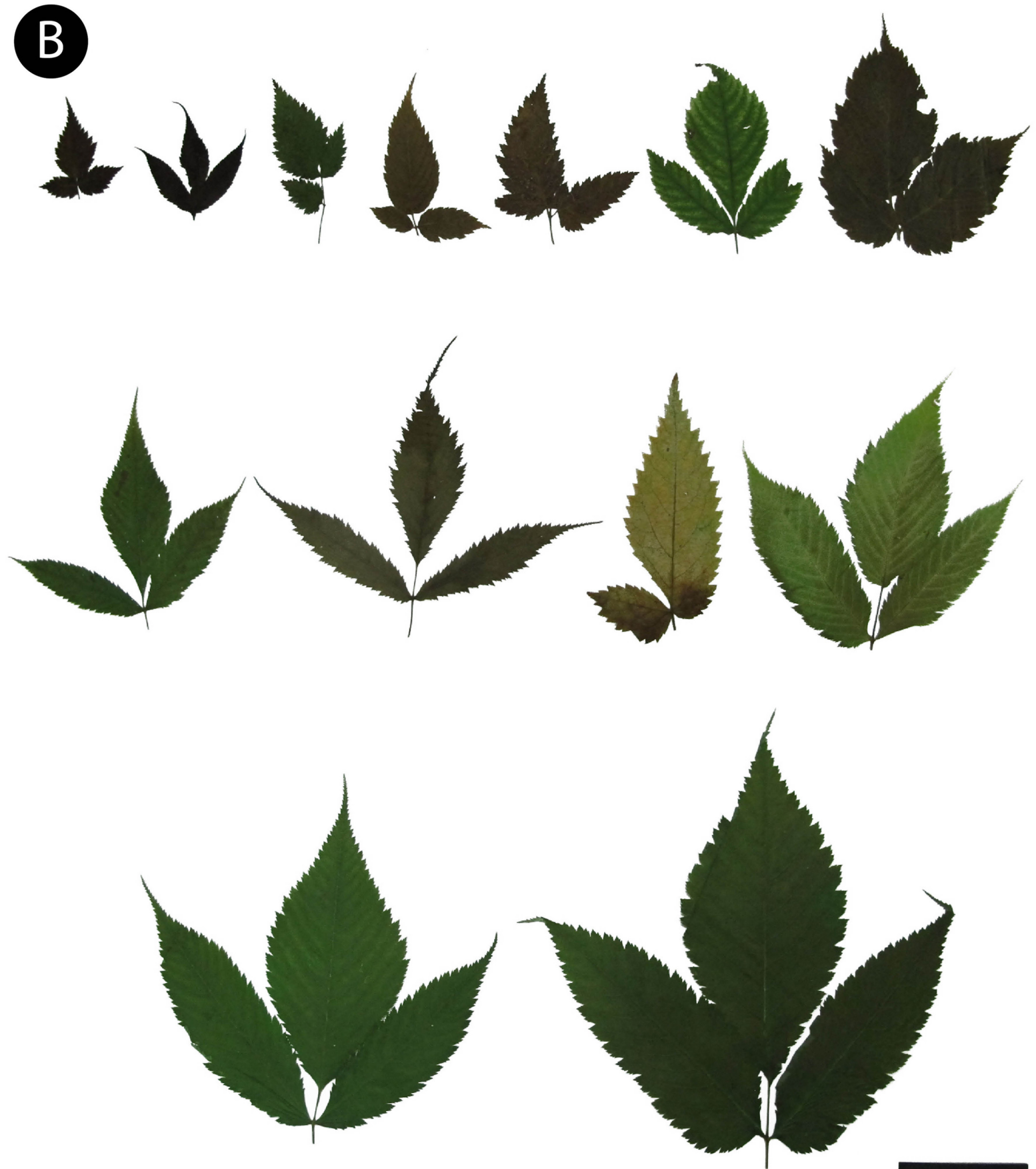

Fig. 1. Photographs of variation of leaf shape in the genus Aruncus. A. A. dioicus var. aethusifolius. B. A. dioicus var. dioicus. Scale bars $=5 \mathrm{~cm}$. 

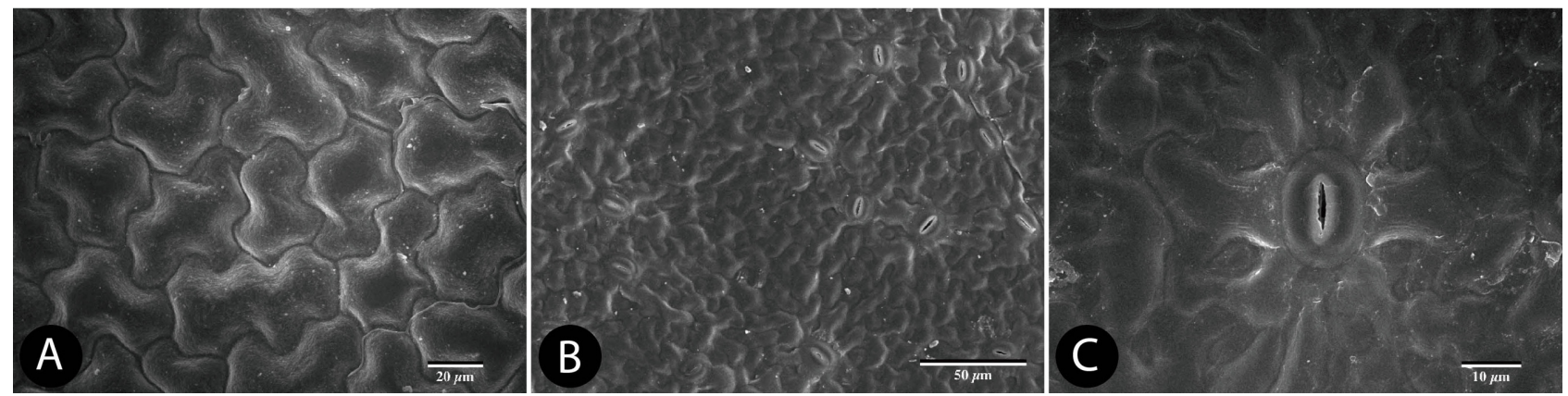

Fig. 2. Scanning electron microscopy micrographs of leaf surface in the genus Aruncus. A. A. gombalanus. Adaxial surface showing undulate epidermal cells with smooth periclinal wall. B. A. dioicus var. dioicus. Adaxial surface showing undulate epidermal cells with smooth periclinal wall. C. A. dioicus var. dioicus. Abaxial surface showing undulate anticlinal walls with anomocytic stomata.

Table 1. Stomata size and frequency on abaxial surface of the genus Aruncus.

\begin{tabular}{lccc}
\hline \hline \multirow{2}{*}{ Taxon } & Length $(\mu \mathrm{m})$ & Stomata complex & \\
\cline { 2 - 4 } & $15.34 \pm 1.73(12.15-19.21)$ & $11.20 \pm 1.42(8.47-14.97)$ & Frequency $^{\mathrm{a}}$ \\
\hline A. dioicus var. dioicus & $13.33 \pm 1.67(10.58-16.35)$ & $10.56 \pm 1.14(8.68-13.16)$ & 14.8 \\
A. dioicus var. acuminatus & $14.53 \pm 1.36(11.52-17.26)$ & $10.49 \pm 1.14(7.50-13.14)$ & 30.8 \\
A. dioicus var. aethusifolius & $18.01 \pm 2.01(13.74-21.94)$ & $13.47 \pm 1.35(10.89-16.89)$ & 19.8 \\
A. dioicus var. astilboides & $13.82 \pm 2.58(8.95-21.97)$ & $10.71 \pm 1.91(7.52-16.99)$ & 30.8 \\
A. dioicus var. pubescens & $15.32 \pm 1.44(12.94-18.27)$ & $12.17 \pm 1.45(9.43-14.62)$ & 24.6 \\
A. dioicus var. vulgaris & $11.11 \pm 1.64(8.50-16.49)$ & $8.94 \pm 1.12(7.51-13.10)$ & 60.4 \\
A. gombalanus &
\end{tabular}

${ }^{a}$ Number of stomata per $0.05 \mathrm{~mm}^{2}$; numbers refer to mean \pm standard deviation (minimum-maximum).

(Cressington Sputter Coater 108, Ted Pella Inc., Redding, CA, USA)를 이용하여 백금 $(\mathrm{Pt})$ 으로 2분간 이온증착(Ion-coating) 하였으며, 전계방출형 주사전자현미경(field emission SEM; JSM-7600F, JEOL, Japan)으로 WD (working distance) 8$10 \mathrm{~mm}$, 가속전력 $10 \mathrm{kv}$ 에서 관찰하였다. 기공과 모용의 크기는 Macnification program (2.0 version, Orbicule, Leuven, Belgium)으로 측정하였고, 기공의 크기는 30 개를 최소 단위 로 측정하여, 평균 \pm 표준편차(최소-최대)로 나타냈으며, 기 공의 빈도는 일정 면적 $\left(0.05 \mathrm{~mm}^{2}\right)$ 에 분포하는 수를 세었다.

잎 표피 미세형질에 관한 용어는 Wilkinson (1979), Barthlott (1981), Stace (1984)를 주로 따랐고, 모용의 형태 는 Theobald et al. (1979)을 참고하였다.

\section{결과 및 고찰}

본 연구결과 얻어진 눈개승마속 7 분류군의 일반적인 잎 표피 미세형태학적 특징들은 Tables 1, 2에 정리하였으 며, Figs. 2, 3에 제시하였다.

\section{잎의 표피세포 및 기공의 미세형태}

표피세포는 향축면(adaxial surface)과 배축면(abaxial surface) 모두에서 동일하게 파상형(undulate)의 수층벽 (anticlinal wall)이 관찰되었고, 병층벽(periclinal wall)은 매 끈하며, 편평하게 나타났다. 특히 배축면의 표피세포는 향축면에 비해 세포간의 경계가 뚜렷하게 나타나지 않았 다(Fig. 2A, B). 또한 속 내 모든 분류군에서 표피상납질은 발달되지 않는 것으로 확인되었다(Figs. 2, 3).

잎 표피세포의 수층벽 형태는 식물의 생육환경과 밀접 하게 연관되어 있고, 일반적으로 직선형이거나(straight) 곡선형(curved)의 수층벽은 건조한 환경의 식물에서, 파상 형의 수층벽은 습한 환경에 서식하는 식물에서 나타난다 고 보고되어 있다(Stace, 1965). 본 속은 고산의 산 사면 및 계곡 등 비교적 습도가 높은 지역에서 자생한다고 알려진 바(Tutin, 1968; Gu and Alexander, 2003; Lee, 2007), 본 연구 에서 확인된 잎 표피세포 형태는 파상형의 수층벽을 나타 내어 표피세포 형태와 환경 요인과의 연관성을 제시한 이 전의 가설을 지지하였다.

눈개승마속 내 모든 분류군은 잎의 기공이 배축면에만 분포하는 이면기공엽(hypostomatic type)으로 나타났으며 (Fig. 2A, B), 기공복합체의 형태는 모두 불규칙형 (anomocytic)으로 확인되었고, 공변세포는 표피세포와 평 행하게 위치하고 있는 것으로 관찰되었다(Fig. 2C). 공변 
Table 2. Distribution pattern and frequency of trichome types in the genus Aruncus.

\begin{tabular}{|c|c|c|c|c|c|c|c|c|c|c|}
\hline \multirow[b]{3}{*}{ A. dioicus var. dioicus } & \multicolumn{4}{|c|}{ Adaxial } & \multicolumn{4}{|c|}{ Abaxial } & \multirow{2}{*}{\multicolumn{2}{|c|}{ Margin }} \\
\hline & \multicolumn{2}{|c|}{ surface } & \multicolumn{2}{|c|}{ midrib } & \multicolumn{2}{|c|}{ surface } & \multicolumn{2}{|c|}{ midrib } & & \\
\hline & s2 & \pm & g & + & s2 & \pm & s2 & \pm & s2 & \pm \\
\hline A. dioicus var. acuminatus & s2 & + & $\mathrm{g}$ & ++ & s2 & + & s2 & + & s2 & ++ \\
\hline A. dioicus var. aethusifolius & $\mathrm{s} 2, \mathrm{~s} 3$ & + & g & + & s2 & \pm & s2, s3 & \pm & s2 & + \\
\hline A. dioicus var. astilboides & - & - & $\mathrm{g}$ & + & - & - & - & - & - & - \\
\hline A. dioicus var. pubescens & s2 & + & $\mathrm{g}$ & + & s2 & ++ & s1 & + & s2 & + \\
\hline A. dioicus var. vulgaris & s2 & \pm & $\mathrm{g}$ & + & $\mathrm{s} 2$ & \pm & s3 & + & - & - \\
\hline A. gombalanus & - & - & $\mathrm{g}$ & + & - & - & s1 & ++ & - & - \\
\hline
\end{tabular}

g, short stalked capitate glandular trichome; s1, unicellular trichome without subsidiary cells on the basal of trichome; s2, unicellular trichome with one layered subsidiary cells on the basal of trichome; s3, unicellular trichome with pustulosed subsidiary cells on the basal of trichome; -, absent \pm , absent or present; +, present; ++, dominant.

세포를 포함한 기공의 크기는 평균 $11.11-18.01 \times 8.94$ $13.47 \mu \mathrm{m}$ 이었으며, 길이/폭 비율의 평균은 $0.73-0.81$ 로 분 류군에 따라 다소 차이가 있는 것으로 나타났다(Table 1). 연구된 분류군 중 A. dioicus var. astilboides가 평균 크기 $18.01 \times 13.47 \mu \mathrm{m}$ 로 가장 큰 기공을 갖는 것으로 나타났고, A. gombalanus 가 평균 크기 $11.11 \times 8.94 \mu \mathrm{m}$ 로 가장 작게 나 타났다(Table 1). 일정 면적당 기공의 빈도는 면적당 $\left(0.05 \mathrm{~mm}^{2}\right)$ 평균 27.54 개로, A. gombalanus에서 평균 60.4 개 $/ 0.05 \mathrm{~mm}^{2}$ 로 가장 높게, A. dioicus var. acuminatus에서 평균 11.6 개 $/ 0.05 \mathrm{~mm}^{2}$ 로 가장 낮게 관찰되었다(Table 1).

눈개승마속 내 분류군은 모두 이면기공엽으로 확인되 었으며, 기공복합체의 형태 역시 불규칙형으로 분류군 간 에 차이가 없는 것으로 밝혀졌다. 따라서, 본 속에서는 일 관성 있게 나타나는 기공의 분포 및 기공복합체의 유형이 지리적 변이와 환경적 요인으로부터 비교적 안정적인 형 질로 판단되었다. 한편, 기공복합체의 크기 및 빈도는 분 류군 간 차이가 나타났는데, 특히 A. gombalanus는 상대적 으로 크기가 작고, 높은 빈도로 기공이 분포하여 속 내 다 른 분류군과 뚜렷하게 구별되었다(Table 1). 기공의 발달 은 온도, 빛 등 환경적 요인에 의해 영향을 받는다고 알려 져 있으며, 기공 특징들에서 나타나는 다양한 변이는 개 체의 유전체(genome), 생육형(growth form), 서식지 환경 (environment) 등과 연관 지어 설명될 수 있다(Capellades et al., 1990; Hetherington and Woodward, 2003; Beaulieu et al., 2008). 특히 햇볕이 강하고, 건조한 환경일수록 식물체에 서는 작은 크기의 기공이 일정 면적당 높은 빈도로 분포 한다고 알려져 있다(Hetherington and Woodward, 2003). 이 러한 작은 크기의 기공은 수분스트레스에 빠르게 반응할 수 있으며, 높은 빈도의 분포는 광합성을 하는 동안 요구 되는 이산화탄소 확산의 효율을 증가 시킬 수 있다는 장 점을 지닌다(Tarnavschi and Pauca Comanescu, 1972; Wilkinson et al., 1979; Hetherington and Woodward, 2003). 또한 실제 일부 초본성 식물의 경우 고도가 높아질수록
기공의 크기가 작아지는 경향성이 보고된 바 있다 (Tarnavschi and Pauca Comanescu, 1972). A. gombalanus는 $3,000-4,500 \mathrm{~m}$ 의 비교적 높은 고도에서 자생하는 것으로 알려져 있고 $(\mathrm{Gu}$ and Alexander, 2003; Pathak and Bhaumik, 2012), 본 연구결과 상대적으로 크기가 작으며, 높은 빈도 로 분포하는 기공을 갖는 것으로 밝혀졌다. 이는 본 종의 서식지 환경 특성과 연관된 형질로서 설명될 수 있으며, 기공의 크기 및 빈도와 환경과의 연관성에 대한 이전의 연 구 결과와 유사한 경향성이 나타남을 확인할 수 있었다.

\section{모용의 형태 및 분포}

본 연구에서 관찰된 눈개승마속 분류군의 모용은 분비 구조의 유무에 따라 선모(glandular trichome, g)와 비선모 (non-glandular trichome, s)로 구분할 수 있었다. 각 분류군 에서 나타나는 모용의 종류와 분포 및 빈도는 Table 2에 정 리하였다.

짧은 자루의 두상선모(short stalked capitate glandular trichomes)는 여러 개의 세포로 이루어진 자루와 분비구조 인 두상세포로 이루어져 있고, 조사된 모든 분류군에서 공통적으로 잎의 향축면 맥 위에만 분포하는 것으로 관찰 되었다(Fig. $3 \mathrm{G}, \mathrm{H})$. 다만, A. dioicus var. acuminatus의 경우 두상선모가 상대적으로 높은 빈도로 관찰되어 속 내 다른 분류군들과 구별되었다(Table 2).

본 연구 분류군에서는 세 종류의 비선모가 확인되었다. 모용의 기저부분을 둘러싸는 부세포(subsidiary cells)의 유 무와 발달 정도에 따라 부세포가 존재하지 않는 단세포 단모(s1) (Fig. 3I), 부세포와 표피세포의 높이가 비슷하게 형성되는 단세포 단모(s2) (Fig. 3J), 부세포가 한 층 이상으 로 발달되며 표피세포보다 높게 형성(protuberant)되는 단 세포 단모(s3) (Fig. 3K)로 구분하였다. 이러한 비선모 계열 의 모용들은 그 길이가 $200 \mu \mathrm{m}$ 에서 $500 \mu \mathrm{m}$ 이상까지 다양 하게 관찰되었고, 잎의 양면 전반에 걸쳐 분포하였으며, 그 분포 패턴 및 빈도는 분류군 간에 차이가 나타났다(Fig. 


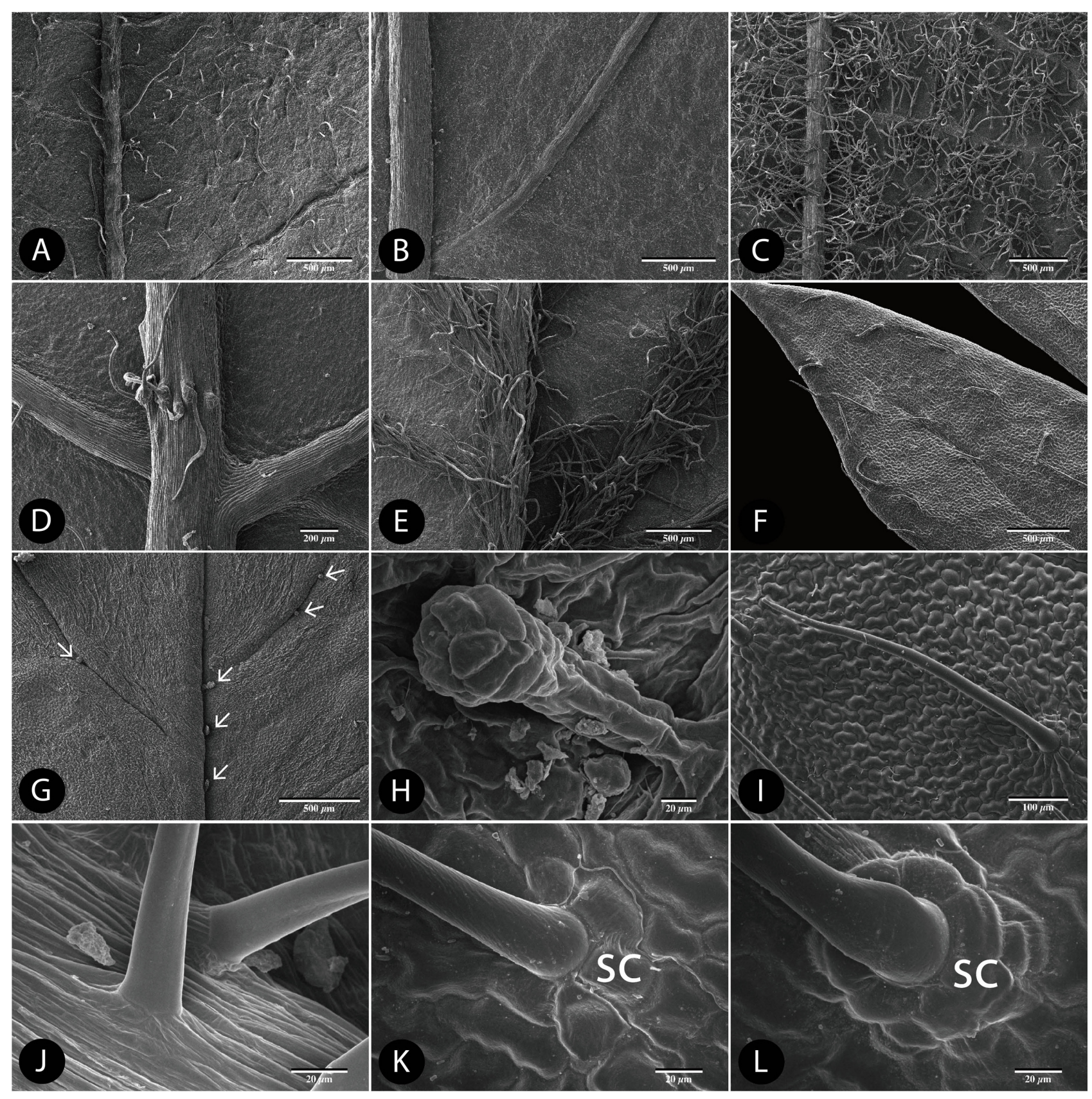

Fig. 3. Scanning electron microscopy micrographs of distribution patterns and types of trichome in the genus Aruncus. A. A. dioicus var. acuminatus. Distribution of unicellular trichomes with one layered subsidiary cells on the basal of trichomes (s2) on the abaxial surface. B. A. dioicus var. astilboides. Glabrous on the abaxial surface. C. A. dioicus var. pubescens. Densely distribution of unicellular trichomes (s1, s2) on the abaxial surface. D. A. dioicus var. vulgaris. Distribution of unicellular trichomes with pustulosed subsidiary cells on the basal of trichomes (s3) at the abaxial surface mid vein. E. A. gombalanus. Densely distribution of unicellular trichomes without subsidiary cells on the basal of trichomes (s1) at the abaxial surface mid vein. F. A. dioicus var. aethusifolius. Distribution of unicellular trichomes (s2, s3) on the adaxial surface. G. $A$. gombalanus. Distribution of short stalked capitate glandular trichomes (g; arrows) on the adaxial surface. H. $A$. dioicus var. acuminatus. Distribution of short stalked capitate glandular trichome (g) on the adaxial surface. I. A. dioicus var. aethusifolius. Distribution of unicellular trichomes with one layered subsidiary cells on the basal part (s2) on the abaxial surface. J. A. dioicus var. pubescens. Distribution of unicellular trichomes without subsidiary cells on the basal part (s1) on the abaxial surface. K. A. dioicus var. dioicus. Distribution of unicellular trichome with one layered subsidiary cells on the basal part (s2) on the abaxial surface. L. A. dioicus var. aethusifolius. Distribution of unicellular trichome with protuberant two layered subsidiary cells on the basal part (s3) on the abaxial surface. SC, subsidiary cell. 
3A-F, Table 2). A. gombalanus의 경우, 배축면의 중륵과 세 맥을 따라 길이 $500 \mu \mathrm{m}$ 이상의 단세포 단모(s1)가 비교적 높은 빈도로 분포하는 것으로 나타났고(Fig. $3 \mathrm{E})$, A. dioicus var. pubescens는 s1, s2 두 종류의 모용이 혼재되어 배축면 의 다양한 부위에 비교적 높은 빈도로 분포하는 특징을 나타냈다(Fig. 3C). 또한, s3의 모용은 조사된 분류군 중 $A$. dioicus var. aethusifolius 의 잎의 표면과 중륵, 그리고 $A$. dioicus var. vulgaris 중륵에서만 관찰되어 구분되었다(Fig. $3 \mathrm{D}, \mathrm{K})$.

식물의 잎에 분포하는 모용은 생물적, 비생물적 스트레 스로부터 식물을 보호하며, 분류학적으로도 유용한 가치 를 지니는 것으로 많은 연구에 의해 밝혀졌다(Roy et al., 1999; Zorić et al., 2009; Sunami et al., 2012). 특히, 장미과 내 다양한 분류군과 계급에서 잎 표피 내 모용 형태의 분류 학적 유용성이 이미 검증된 바 있다(Eriksen and Yurstev, 1999; Kolodziejek, 2008; Faghir et al., 2010; Ganeva and Uzunova, 2010; Heo et al., 2013; Faghir et al., 2014; Tomaszewski et al., 2014; Song and Hong, 2016, 2017). 눈개 승마속 분류군의 잎 표피 관찰 결과, 총 4 가지 유형의 모용 이 확인되었고, 각 분류군들에 존재하는 모용의 종류 및 분포양상은 일부 분류군 간 변이가 나타나는 것으로 밝혀 졌다. 단세포 단모와 함께 짧은 자루의 두상선모가 조사 된 모든 분류군에서 공통적으로 확인되었으며, 두상선모 의 분포 패턴은 비교적 높은 빈도로 분포하는 A dioicus var. acuminatus를 제외하고, 분류군 간에 차이가 없었다. 하지만, 비선모인 단세포 단모의 경우 형태와 빈도에서 분류군 간 차이가 존재하는 것으로 나타났다. 속 내에서 독립된 종으로 인식되기도 하는 A. gombalanus는 배축면 의 중륵과 세맥에만 단세포 단모(s1)가 높은 빈도로 분포 하며, 중륵과 세맥을 제외한 양면 모두에서 무모인 특징 을 나타냈다. 이는 잎의 양면에 단세포 단모가 분포하지 않는 A. dioicus var. astilboides, 잎의 양면과 엽연에 적어도 한 가지 이상의 단세포 단모가 다양한 빈도로 분포하는 $A$. dioicus 및 A. dioicus var. astilboides를 제외한 종하위 분류 군과 차이를 나타내는 것으로 밝혀졌다.

Hara (1955), Mellichamp (2014) 등에 의해 배축면에 모용 이 밀생하는 특징에 따라 변종으로 인식되는 A. dioicus var. pubescens는 본 연구결과 A. dioicus를 포함한 종하위 분류군과 동일한 유형의 모용을 갖지만, 다른 분류군들과 달리 중륵을 포함한 잎의 배축면 전반에 두 종류의 비선 모가 균일하게 밀생하여 분포하는 경향을 갖는 것으로 확 인되었다. 한편, Hara (1995)에 의해 소화경이 직립하는 특 징으로 다른 분류군과 뚜렷하게 구별되어 인식되는 $A$. dioicus var. astilboides는 잎의 배축면이 무모이고, 향축면 에 단세포 단모가 분포하지 않는 특징으로 속 내 다른 분 류군과 구별되는 것으로 밝혀졌다. A. dioicus var. aethusifolius는 양면에 s2, s3의 모용이 혼재되어 나타나, 나 머지 종하위 분류군과 구별되었다(Table 2).
잎에 분포하는 모용의 빈도는 유전적, 환경적 요인 모두 에 영향을 받는다고 알려져 있으며, 특히 장미과 내 양지 꽃족(tribe Potentilleae)에서는 종간 모용의 유무에 대한 차 이가 존재하고, 종 내 개체들 사이에는 모용의 빈도에 다 양한 변이가 발생할 가능성이 있는 것으로 알려져 있다 (Heo et al., 2013). 잎 모용의 미세형태는 조사된 모든 개체 에서 뚜렷하게 구분되는 특징을 보인 A. gombalanus와 $A$. dioicus var. aethusifolius, $A$. dioicus var. astilboides, $A$. dioicus var. pubescens의 중요한 식별형질로서 사용될 수 있을 것 이다. 특히, A. dioicus var. aethusifolius는 소엽 결각 상태의 차이(Fig. 1), 화분 크기와 표면 무늬의 차이(Ok and Hong, 2015) 등과 더불어 본 연구에서 확인된 모용의 종류와 분 포 차이의 결과를 종합하여 볼 때, 본 분류군을 종 수준으 로 인식한 Nakai (1912)의 견해를 지지하였다.

본 연구에서 조사된 눈개승마속 분류군의 기공 크기와 빈도, 표피세포의 미세형태, 모용의 종류와 분포양상 등 의 형질은 일부 분류군간 변이가 존재하는 것으로 나타났 다. 그 중에서도 기공의 크기와 빈도, 모용의 분포양상과 빈도 등의 특징은 속 내 일부 분류군을 구별하는 데 유용 한 것으로 밝혀졌다. 나아가 불규칙형의 기공형태와, 이 면기공엽인 특징, 두상선모의 분포는 눈개승마속 내 모든 분류군에서 일관성 있게 관찰되는 대표형질임이 밝혀졌 다. 추후, 분자계통학적 연구를 비롯한 추가적인 형질 연 구를 통해 눈개승마속 내 분류군의 종 또는 종하위 분류 군의 한계설정 및 분류학적 재개정이 수행되어야 할 것이 며, 본 잎 표피 미세형태학적 연구 결과는 이를 위한 추가 적인 자료로 유용하게 활용될 수 있을 것이다.

\section{Acknowledgments}

We would like to thank the directors of the herbaria of F, KB, KHUS, NY, PE, and TI for permitting the examination of specimens through loans. Two anonymous reviewers, whose comments and corrections improved the work, are also acknowledged. This study is supported by the Basic Science Research Program through the National Research Foundation of Korea (NRF) funded by the Ministry of Education, Sciences and Technology (NRF-2012R1A1A2004149) to S.-P. Hong.

\section{Conflict of Interest}

Authors declare that there is no conflict of interest.

\section{Literature Cited}

Anil Kumar, V. S. and K. Murugan. 2013. Taxonomic significance of foliar micromorphology and their systematic relevance in the genus Solanum (Solanaceae). In Prospects in 
Bioscience: Addressing the Issues. Sabu A. and A. Augustine (eds.), Springer, Kolkata. Pp. 343-349.

Barthlott, W. 1981. Epidermal and seed surface characters of plants: systematic applicability and some evolutionary aspects. Nordic Journal of Botany 1: 345-355.

Beaulieu, J. M., I. J. Leitch, S. Patel, A. Pendharkar and C. A. Knight. 2008. Genome size is a strong predictor of cell size and stomatal density in angiosperms. New Phytologist 179: 975-986.

Capellades, M., R. Fontarnau, C. Carulla and P. Debergh. 1990. Environment influences anatomy of stomata and epidermal cells in tissue-cultured Rosa multiflora. Journal of the American Society for Horticultural Science 115: 141-145.

Chang, C.-S., H. Kim and K. S. Chang. 2014. Provisional Checklist of Vascular Plants for the Korea Peninsula Flora (KPF). Designpost, Seoul, $561 \mathrm{pp}$.

Deng, M., A. Hipp, Y.-G. Song, Q.-S. Li, A. Coombes and A. Cotton. 2014. Leaf epidermal features of Quercus subgenus Cyclobalanopsis (Fagaceae) and their systematic significance. Botanical Journal of the Linnean Society 176: 224-259.

Eriksen, B. and B. A. Yurtsev. 1999. Hair types in Potentilla sect. Niveae (Rosaceae) and related taxa, terminology and systematic distribution. Norske Videnskaps-Akademi MatematiskNaturvidenskapelig Klasse, Skrifter, Ny Serie 38: 201-221.

Faghir, M. B., F. Attar, A. Farazmand, B. Ertter and B. Eriksen. 2010. Leaf indumentum types in Potentilla (Rosaceae) and related genera in Iran. Acta Societatis Botanicorum Poloniae 79: 139-145.

Faghir, M. B., K. K. Chaichi and R. S. Shahvon. 2014. Foliar epidermis micromorphology of the genus Alchemilla (Rosaceae) in Iran. Phytologia Balcanica 20: 215-225.

Fernald, M. L. 1939. IV. New species, varieties and transfers. Rhodora 41: 423-461.

Ganeva, T. and K. Uzunova. 2010. Comparative leaf epidermis study in species of genus Malus Mill. (Rosaceae). Botanica Serbica 34: 45-49.

Gu, C. and C. Alexander. 2003 Aruncus L. In Flora of China. Vol. 9. Pittosporaceae through Connaraceae. Wu, Z. Y., P. H. Raven and D. Y. Hong (eds.), Science Press, Beijing \& Missouri Botanical Garden Press, St. Louis, MO. Pp. 74-75.

Hara, H. 1955. Critical notes on some type specimens of East-Asiatic plants in foreign herbaria (2). Journal of Japanese Botany 30: $65-72$.

Heo, K. I., S. R. Lee, M. H. Yoo, S. T. Lee, Y. Kwon, S. Y. Lim, S. H. Kim and S. C. Kim. 2013. The taxonomic implication of trichome and epicuticular waxes in tribe Potentilleae (Rosaceae) in Korea. Korean Journal of Plant Taxonomy 43: 106-117. (in Korean)

Hetherington, A. M. and F. I. Woodward. 2003. The role of stomata in sensing and driving environmental change. Nature 424: 901-908.
Hutchinson, J. 1964. The Genera of Flowering Plants. Vol. 1. Dicotyledons. Clarendon Press, Oxford, 510 pp.

Ikeda, H. 2001. Aruncus L. In Flora of Japan. Vol. IIb. Angiospermae; Dicotyledoneae; Archichlamideae (b). Iwatsuki, K., T. Yamazaki, D. E. Boufford and H. Ohba (eds.), Kodansha, Ltd., Tokyo. Pp. 100-102.

Kalkman, C. 2004. Rosaceae. In The Families and Genera of Vascular Plants. Vol. 6. Flowering Plants, Dicotyledons: Celastrales, Oxalidales, Rosales, Cornales, Ericales. Kubitzki, K. (ed.), Springer-Verlag, Berlin. Pp. 343-386.

Kang, Y., F. Jabbour, S. Cao, Y. Wang, J. Guo and J. Huang. 2017. Leaf epidermal features of Chinese Stephania Lour. (Menispermaceae) and their systematic significance. Kew Bulletin 72: 26.

Kołodziejek, J. 2008. Hair types in Polish selected taxa of Potentilla subsect. Collinae (Rosaceae). Acta Societatis Botanicorum Poloniae 77: 217-224.

Lee, S. T. 2007. Aruncus L. In The Genera of Vascular Plants of Korea. Park, C.-W. (ed.), Academy Publishing Co., Seoul. Pp. 541-542.

Lee, T. B. 1980. Illustrated Flora of Korea. Hyangmunsa, Seoul, 791 pp. (in Korean)

Mellichamp, T. L. 2014. Aruncus L. In Flora of North America: North of Mexico. Vol. 9. Magnoliophyta: Picramniaceae to Rosaceae. Flora of North America Editorial Committee (ed.), Oxford University Press, New York and Oxford. Pp. 422-424.

Nakai, T. 1912. Notulæ ad Plantas Japoniæ et Coreæ VIII. The Botanical Magazine 26: 321-328.

Ok, M.-K. and S.-P. Hong. 2015. Pollen morphology of the genus Aruncus L. (Rosaceae). Korean Journal of Plant Taxonomy 45: 323-331.

Pathak, M. K. and M. Bhaumik. 2012. Aruncus gombalanus (Rosaceae): a new record for India. Rheedea 22: 133-135.

Rydberg, P. A. 1908. Rosaceae. In North American Flora. Vol. 22. Part 3. Britton, N. L., F. V. Coville, H. A. Gleason, J. K. Small, C. L. Pollard and P. A. Rydberg (eds.), The New York Botanical Garden, New York. Pp. 239-292.

Roy, B. A., M. L. Stanton and S. M. Eppley. 1999. Effects of environmental stress on leaf hair density and consequences for selection. Journal of Evolutionary Biology 12: 1089-1103.

Song, J.-H. and S.-P. Hong. 2016. Taxonomic significance of the leaf micromorphology in the tribe Sorbarieae (Spiraeoideae: Rosaceae). Korean Journal of Plant Taxonomy 46: 199-212. (in Korean)

Song, J.-H. and S.-P. Hong. 2017. The systematic implications of leaf micromorphological characteristics in the tribe Neillieae (Spiraeoideae, Rosaceae). Korean Journal of Plant Taxonomy 47: 222-235. (in Korean) 
Stace, C. A. 1965. Cuticular studies as an aid to plant taxonomy. Bulletin of the British Museum (Natural History) Botany 4: 378.

Stace, C. A. 1984. The taxonomic importance of the leaf surface. In Current Concepts in Plant Taxonomy. Heywood, V. H. and D. M. Moore (eds.), Academic Press, London. Pp. 67-93.

Sunami, T., K. Ohga, M. Muroi, H. Hayakawa, J. Yokoyama, K. Ito, S. Tebayashi, R. Arakawa and T. Fukuda. 2012. Comparative analyses of hairless-leaf and hairy-leaf type individuals in Aster hispidus var. insularis (Asteraceae). Journal of Plant Studies 2: 1-6.

Tarnavschi, I. and M. Pauca Comanescu. 1972. Morphological variation of leaf epidermis depending on station in several herbaceous species. Revue Roumaine de Biologie Serie de Botanique 7: 299-309.

Theobald, W. L., J. L. Krahulik and R. C. Rollins. 1979. Trichome description and classification. In Anatomy of the Dicotyledons. 2nd ed. Vol. I. Metcalfe, C. R. and L. Chalk (eds.), Clarendon Press, Oxford. Pp. 40-53.

Thiers, B. 2017. (continuously updated) Index Herbariorum: a global directory of public herbaria and associated staff. New York Botanical Garden's Virtual Herbarium. Retrieved Jul. 10, 2017, available from http://sweetgum.nybg.org/ih/.

Tomaszewski, D., J. Zieliński and M. Gawlak. 2014. Foliar indumentum in central-European Rubus species (Rosaceae) and its contribution to the systematics of the group. Nordic Journal of Botany 32: 1-10.

Tutin, T. G. 1968. Aruncus L. In Flora Europaea. Vol. 2. Rosaceae to Umbelliferae. Tutin, T. G., V. H. Heywood, N. A. Burges, D. M. Moore, D. H. Valentine, S. M. Walters and D. A. Webb (eds.), Cambridge University Press, Cambridge. Pp. 3-6.

Wilkinson, H. P. 1979. The plant surface (mainly leaf). In Anatomy of the Dicotyledons. Vol. I. Systematic Anatomy of Leaf and Stem, with a Brief History of the Subject. 2nd ed. Metcalfe, C. R. and L. Chalk (eds.), Clarendon Press, Oxford. Pp. $97-165$.

Yang, Z.-R. and Q. Lin. 2005. Comparative morphology of the leaf epidermis in Schisandra (Schisandraceae). Botanical Journal of the Linnean Society 148: 39-56.

Yuzepchuk, S. V. 1939. Aruncus. In Flora of the U.S.S.R. Vol 4. Rosales and Sarraceniales. Izdatel"stvo Akademii Nauk SSSR. Komarov, V. L. (ed.), Moscow, Leningrad. Pub. by Israel Program for Scientific Translations Ltd., Jerusalem. Pp. 238-240.

Zhou, Z. K., H. Wilkinson and Z. Y. Wu. 1994. Taxonomical and evolutionary implications of the leaf anatomy and architecture of Quercus L. subgenus Quercus from China. Cathaya 7: 134.

Zorić, L., L. Merkulov, J. Luković, P. Boža and D. Polic. 2009. Leaf epidermal characteristics of Trifolium L. species from Serbia and Montenegro. Flora 204: 198-209.

\title{
눈개승마속(장미과) 잎 표피 미세형태학적 형질 및 분류학적 유용성
}

\author{
옥민경 ${ }^{1} \cdot$ 송준호 $^{1,2} \cdot$ 홍석표 $^{1 *}$ \\ ${ }^{1}$ 경희대학교 이과대학 생물학과, ${ }^{2}$ 한국한의학연구원 한약연구부
}

\begin{abstract}
적 요. 눈개승마속 2 종 5 변종등 7 분류군의 잎 표피 미세형태학적 형질에 대한 분류학적 유용성을 검토하고 자 주사전자현미경(scanning electron microscopy)을 이용하여 관찰하고, 기재하였다. 본 속에 속하는 모든 분 류군에서 기공복합체(stomatal complex)는 배축면에만 기공이 존재하는 이면기공엽(hypostomatic type)이었으 며, 표피세포는 양면 모두에서 동일하게 파상형(undulate)의 수층벽(anticlinal wall), 매끈하고, 편평한 병층벽

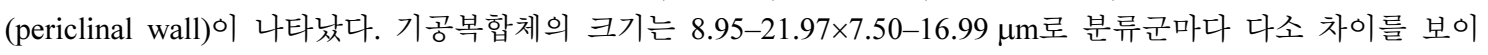
는데, Aruncus dioicus var. astilboides (평균 $18.01 \times 13.47 \mu \mathrm{m}$ )가 가장 크게 나타났으며, A. gombalanus (평균 $11.11 \times 8.94 \mu \mathrm{m}$ )에서 가장 작게 나타났다. 기공복합체의 형태는 모두 불규칙형(anomocytic)으로 확인되었다. 기공의 빈도는 면적당 $\left(0.05 \mathrm{~mm}^{2}\right)$ 평균 27.54 개로, A. gombalanus에서 가장 높은 빈도 $\left(60.4\right.$ 개/ $\left./ 0.05 \mathrm{~mm}^{2}\right), A$. dioicus var. acuminatus에서 가장 낮은 빈도 $\left(11.6\right.$ 개 $\left./ 0.05 \mathrm{~mm}^{2}\right)$ 로 관찰되었다. 연구된 분류군에서 나타나는 모 용의 종류는 크게 2종류로 짧은 자루의 두상선모(short stalked capitate glandular trichome)와 비선모(nonglandular trichomes)가 확인되었고, 비선모는 부세포(subsidiary cells)의 유무와 발달 정도에 따라 세 가지 타 입으로 구별되었다. 불규칙형의 기공형태와 이면기공엽, 두상선모의 분포는 본 속을 인식하는 주요형질로 판 단되었으며, 기공의 크기와 빈도, 표피세포의 미세형태, 모용의 종류와 분포양상 등은 일부 분류군을 구별하 는 인식형질로 유용한 것으로 나타났다. 잎 표피 내 다양한 미세형태학적 형질은 외부형태학적 형질과 더불 어 본 속의 분류학적 개정을 위해 보다 유용한 정보를 제공할 것이다.
\end{abstract}

주요어: 잎 표피세포, 기공복합체, 선모, 눈개승마속, 장미과 
Appendix 1. Voucher specimens of genus Aruncus that are examined in the present study.

Taxa Voucher specimens

Aruncus dioicus L. var. dioicus (Walter) Fernald

Korea, Seoul, Achasan Mt., 20 May 2014, Song and Oak 1800001 KHUS

Korea, Gyeonggi-do, 20 May 2014, Song and Oak 050520 KHUS

Korea, Gyeongsangnam-do, Namdeogyusan Mt., 17 Jun 2006, Sun VP7400015156 KB

A. dioicus var. acuminatus (Douglas ex Hook.) H. Hara

USA, Washington, 22 Jul 1930, Aug 1976, without collector's name NY

USA, Oregon, Lincoln Co., 11 Aug 2007, Halse $7342 \mathrm{~F}$

USA, Washington, 21 Jun 1902, Conard $142 \mathrm{~F}$

A. dioicus var. aethusifolius (H. Lév.) H. Hara

Korea, Jejudo Isl., Hallasan Mt., 09 Jul 2012, Choi and Bum VP $0000422303 \mathrm{~KB}$

Korea, Jejudo Isl., Hallasan Mt., 15 Jul 2014, Song and Oak 1800003 KHUS

Korea, Jejudo Isl., Hallasan Mt., 15 Jul 2014, Song and Oak 010714 KHUS

A. dioicus var. astilboides (Maxim.) H. Hara

Japan, Honshu, Hayachinesan Mt., Rikuchu, 21 Jul 1913, without collector's name M14-02(8) TI

Japan, Honshu, Hayachinesan Mt., Rikuchu, 06 Aug 1913, without collector's name M14-02(10) TI

Japan, Honshu, Hayachinesan Mt., Rikuchu, 11 Jul 1913, without collector's name TI

A. dioicus var. pubescens (Rydb.) Fernald

USA, St. Louis Co., 4 Jun 1926, Aug. 1976, without collector's name 1612 F

USA, White River region, W-facing limestone cliff, 08 Jun. 1953, Moore and Iltis F

A. dioicus var. vulgaris (Maxim.) H. Hara

USA, California, Siskiyou county, 20 Aug 1959, Francia Chisaki, Helen K. Sharsmith s.n. NY

USA, Washington, 23 Jul 1893, Sandberg and Leiberg 561 F

A. gombalanus (Hand.-Mazz.) Hand.-Mazz.

China, Mekong-Salween Divide, Sila, 5 Aug 1938, T. T. Yu 00561083 PE

China, Wei-si Hsien, Kang-pum Ditch side, Jul 1935, Wang 0051093 PE

Herbarium acronyms follow Index Herbariorum (Thiers, 2017) [continuously updated] http://sweetgum.nybg.org/science/ih/. 